\title{
Chicano/a Multiplicity and In-betweenness in John Rechy's City of Night
}

\author{
ERIC BERGMAN \\ PhD Candidate, Department of Philosophy, History, \\ Culture and Art Studies, University of Helsinki
}

\begin{abstract}
John Rechy's novel City of Night, published in 1963, predated the Chicano Movement and the scholarly concentration on Mexican American issues that came in the movement's wake. However, many of the subjects that have preoccupied scholars since the beginning of the interdisciplinary field of Chicano Studies, such as the multiplicity of identities in the Chicano/a community, were anticipated in Rechy's novel. Through an analysis of narrative techniques, such as the first person point of view and observational tone, the episodic structure and picaresque genre, this article outlines how multiplicity and in-betweenness, especially in terms of ethnicity and sexuality, are constructed in the novel and can be considered as an example of the conceptual space of nepantla.
\end{abstract}

Key words: Nepantla, Multiplicity, In-betweenness, John Rechy, Chicano Studies

\section{INTRODUCTION}

To state that the Mexican American ethnic community is made up of multiple identity positions, including various languages, religions, sexualities and genders that come from different regions is, in the current paradigm, to make a trite remark. That the multiplicity of identities has not always been acknowledged as such by either the Mexican American community or by the broader American society has also been well established (Peñalosa 2010: 16-27; Gómez-Quiñones 2010: 40-41). However, to consider how the Mexican American community went from being understood by many as a homogenous community to one defined as having a multiplicity of identities is to engage with a subject that is at the heart of Chicano Studies. ${ }^{1}$ Research

\footnotetext{
${ }^{1}$ Chicano Studies will be defined below. The terms "Chicano/a" and "Mexican American" are often used interchangeably and both signify a person from the United States of Mexican descent. Here I use the former to signify individuals or groups that self-identify with the term and the latter in a more neutral and
} 
into the particularities of the Chicano/a experience, including life at the figurative and literal borderlands, bilingualism, ethnic Otherness, regional identity, migration, religious affiliation and more, can be used to draw comparisons to other fields and different geographical locations, communities and ethnicities. In order to outline the process by which multiple and inbetween Chicano/a identities are conveyed and constructed, I will conduct an analysis of the early Chicano/a novel City of Night (1984) by John Rechy. City of Night gave voice to marginalized voices in American society and the Mexican American community, most notably homosexuals, ${ }^{2}$ at a time when a dominant narration of a homogenous Mexican American-ness was beginning to be put forward by the Chicano Movement.

In order to develop an understanding of how the concepts of multiplicity and in-betweenness came to be applied in Chicano Studies, I will begin by presenting a short synopsis of the Mexican American community after World War II, the Chicano Movement of the late 1960s and early 1970s, the scholarly reaction to the Chicano Movement (Bruce-Novoa 1986; Anzaldúa 1987; Aldama 2005; Noriega 2010; Pérez-Torres 2010) and the ongoing scholarly debate, which shows indications of a shift taking place (Anzaldúa 2002; León 2004; Pérez 2007; Delgadillo 2011; Koegeler-Abdi 2013; Medina 2014). By highlighting the major developments in the field of Chicano Studies, the subsequent treatment of City of Night will make clear how the novel anticipated many of the changes in how Chicano/as have been portrayed by scholars at an early stage of the literary and scholarly treatment of these issues. This should be of interest for scholars who wish to use textual sources to analyze representations of multiplicity and in-betweenness as well as for understanding narratives as a means by which the accepted formations of identity categories in our societies are broadened. City of Night illustrates how narratives might anticipate important developments in the way scholars and society come to think of multiple identities and in-betweenness.

technical sense. Some people, such as the author John Rechy (García 2003: 44) do not wish to associate with the term Chicano/a because of its negative associations in the past (see below).

${ }^{2}$ There have been a number of articles celebrating City of Night's $50^{\text {th }}$ anniversary of publication that have commented on the effect the novel has had on readers' perception of themselves as homosexuals in the context of a dominantly heterosexual society (see, for example, Casillo 2013; Barrios 2013). For more on this subject, as well as City of Night's influence on Chicano/a and other readerships, see Beth Hernandez-Jason's dissertation The Act of Reading John Rechy: Transnational Intertexts and Readers (2014). 


\section{CHICANO/AS}

Having fought and died together with every other U.S. social stratum in World War II, Mexican Americans returned home to their communities to discover that, despite their shared sacrifice and communal exercise in democratic amalgamation, equality and civil rights in wartime circumstances did not always extend to peacetime societies. ${ }^{3}$ Despite unprecedented economic growth between the end of World War II and the late 1960s in the USA, Mexican Americans generally did not benefit from the economic situation to the same extent as Anglo-Americans (Vargas 2005: 253-254). Having experienced a form of social equality during the war as soldiers and, for both genders, in the wartime economy at home, Mexican Americans were unwilling to give up these hard-earned civil, social and economic rights, resulting in a new understanding of the injustices taking place in the USA. This, in turn, influenced a heightened level of social activism and organization in the form of social movements against racism and economic and social prejudice, which culminated in the Chicano Movement of the late 1960s (ibid.). Also influenced by other social injustices over the same period, such as the treatment of the African American and homosexual communities as well as the war in Vietnam, this period led to a burgeoning of social movements intent on changing society. Related to the Civil Rights Movement, the Chicano Movement was made up of people who fought for the rights and recognition of Mexican Americans. Rather than accepting the position as Other in the USA, Mexican Americans took the word "Chicano/a", which originally had a derogatory meaning that denoted someone of lower social level and/or an immigrant of recent arrival (Peñalosa 2010: 18), and subverted it by using it with pride. Ethnicity, race, and culture took on new importance as forms of resistance for many in the Mexican American community, which is reflected in the literature and art of the time. ${ }^{4}$

${ }^{3}$ For Mexican Americans, World War II would "indeed prove to be the war that led to substantial headway in the fight toward desegregating public institutions, and lessening, if not eliminating, the intransigent discrimination that had existed since the end of the Texas-Mexico war" (Rodriguez-Rivas 2005: xvi). However, to various degrees, depending on geographical area and other circumstances, economic and social opportunities were still not equal to those of Anglo-Americans. Most notably in Texas, socially segregated schools were prevalent and signs were regularly posted in restaurant windows that informed potential customers that the proprietor would not serve Mexicans or dogs (ibid.).

${ }^{4}$ Below I mention texts that reflect the nationalism that marked the Chicano Movement. Also, visual art by Chicano/as at the time often portrayed Aztec warriors and similar symbols in a way that authenticated the movement through "artistic and liberatory truth [found] in highly idealized visions of an authentic indigenous past" (Hames-García 2000: 466). Daniel Cooper Alarcon has called this the "Aztec Palimpsest" (1997). Anzaldúa analyzes the connection between pre-Columbian Mexican art, customs and food and contemporary Chicano/a cultural production in "Border Arte: Nepantla, el Lugar de la Frontera" (2009). 
In 1970, a new political party was formed by the name of La Raza Unida Party ("United Race Party"). Although the party did not live up to its promises of united Chicano nationalism that would bring about better social opportunities for all Chicano/as, it did draw political attention from both the Democratic and Republican parties, who became more responsive to the Mexican American community as a result. This led to an increase in the number of Hispanics elected to office (Navarro 2000: 271). In the meantime, political organizations and movements such as La Raza helped galvanize Mexican Americans' pride in their own history and culture. Albeit done in essentialist terms that mixed biology with politics, such political movements were intended to benefit the marginalized Mexican American community, and can be understood as emancipatory narratives of resistance and strategies of decolonization (Hernández 2009: 11). This emancipatory version of Chicano/a identity was portrayed in the text With His Pistol in His Hand (1958) by Américo Paredes and the influential epic poem I am Joaquín (1967) by Rodolfo "Corky" Gonzales. These texts present strong, heterosexual male protagonists that fight against the injustices inflicted on the Mexican American ethnic community by the Anglo-American status quo. Other texts, however, criticized this essentialized definition of the Mexican American race that glossed over the multiplicity of internal differences. Authors such as Oscar Zeta Acosta (Autobiography of a Brown Buffalo [1972] and The Revolt of the Cockroach People [1989, originally 1973]), Sheila Ortiz Taylor (Faultline [1982]) and John Rechy represented the margins of the Chicano community, or those individuals and groups that did not fit into the homogenous definition of Mexican American-ness put forward by the Chicano Movement.

Published in 1963 with the central theme of homosexuality and the underground American hustling scene (i.e. male prostitution), John Rechy's City of Night should be understood as a precursor to the changes that were to take place in the Chicano/a community in the late-1960s and early $1970 \mathrm{~s}$ in addition to developments that were to result from scholarly research into Chicano/a issues. City of Night was a best-selling novel in the USA, widely debated by intellectuals, such as James Baldwin, Christopher Isherwood and Norman Mailer, who were notable supporters, as well as those who condemned the novel's subject matter (García 2003: 39; Hernandez-Jason 2014: 110-128). Written as a first person narrative, the novel represents the American demimonde from an unnamed hustler's point of view as he travels from city to city to discover America's overlooked and silenced margins. By writing about the multiplicity and in-betweenness of the Chicano narrator, Rechy anticipated some of the key preoccupations within the scholarly debate that would follow in the wake of the Chicano Movement in the decades to come. 


\section{CRITICAL REACTION TO THE CHICANO MOVEMENT AND CITY OF NIGHT}

Founded in 1970, the journal Aztlán: A Journal of Chicano Studies became an important avenue by which to disseminate knowledge and ideas about Chicano/a issues. The previous year, the Chicano Studies Research Center at UCLA had been founded, symbolizing a new awareness in the United States of the importance of various ethnic groups. According to Aztlán's current editor, Chon Noriega, the purpose of the journal is "scholarly research relevant to or informed by the Chicano experience" (2010: 3). Within this straightforward-seeming subject matter is the mandate to deconstruct the Chicano/a experience, which is to say rather than taking the Chicano/a experience for granted as a shared phenomenon, to discern internal differences, such as class, gender, sexuality, language, religion and region (ibid.). Movements such as La Raza Unida Party and the manifesto El Plan Espiritual de Aztlán ${ }^{5}$ put forward a homogenous, male-centric, heterosexual vision of the Chicano/a experience, which was important in terms of consolidating a constructed Chicano/a identity. Once secured, this could be followed by a stage in which Chicano/a identity was deconstructed and diversified, and this development represents the central tension within the Chicano Studies continuum. Scholars worked to dismantle assumptions written into the founding texts of the Chicano Movement, such as El Plan Espiritual de Aztlán (1969), and bring to the forefront identities, narratives and representations from the margins of the community. Writing about a collection of scholarly papers from the journal Aztlán, the Chicano scholar Rafael Pérez-Torres defined Chicano/a scholarly work in a way that communicates its relational quality across categories and borders that are simultaneously being questioned:

The essays undo the ontological category of singular ethnic otherness that the term "Chicano" sometimes represents. They assume a critical position interrogating the relation between knowledge and power, between self and other, between margin and center. They contest the conditions that have allowed certain forms of knowledge to appear natural while others seem re-

\footnotetext{
${ }^{5}$ Written in 1969 by a collection of Chicano/a activists, El Plan Espiritual de Aztlán is the definitive text on the form of nationalism for which the Chicano Movement is most often remembered today. The opening line illustrates the tone and subject matter of the text as a whole: "In the spirit of a new people that is conscious not only of its proud historical heritage but also of the brutal "gringo" invasion of our territories, we, the Chicano, Mexican, Latino, Indigenous inhabitants and civilizers of the northern land of Aztlan [sic] from whence came our forefathers, reclaiming the land of their birth and consecrating the determination of our people of the sun, declare that the call of our sangre [blood] is our power, our responsibility, and our inevitable destiny" (El Plan 1969). Aztlán is the mythical homeland of the Aztecs, believed to be in the geographical region of the present-day Southwestern United States.
} 
legated to the realm of the exotic. Finally, they seek to redraw the boundaries that set up divisions between knowledge, action, and being. (2010: 411)

The interdisciplinary field of Chicano Studies aims to deconstruct identity formations in order to allow for a creative reconstruction and positioning of those identities through knowledge and action. By critically taking up issues that are framed as binaries ("knowledge and power [...] self and other, [...] margin and center" [ibid.]) many Chicano/a scholars aim to define conceptual spaces that are in-between these dichotomies, as will become clear in the examples below. City of Night is an important example of textual in-betweenness because in it, Rechy bypasses the chronology of development in the understanding of Chicano/a issues outlined here - the founding of a Chicano/a identity followed by the deconstruction and diversification of the original founding idea. Rechy violated these rules by opting, as early as 1963, for a non-consolidated identity, which marks the novel as an important example of how narratives might anticipate conceptual spaces before they have been theorized as such.

The publication in 1979 of a special issue of the journal Minority Voices marked another development in Chicano literary studies and, in particular, research into John Rechy's oeuvre. As described by Chicano scholar Frederick Luis Aldama, this particular journal contextualized Rechy's work within a racial frame (2005: 49). Previously, City of Night had been identified as homosexual literature, as scandalous pulp fiction or as part of the Grove Press avant-garde (ibid.: 47). The novel was now being read as a commentary of racial marginality, which was made possible precisely because of Rechy's sexual orientation, which ostracized him within his already marginalized ethnic group (ibid.: 49). Like the homosexual African American author James Baldwin, Rechy was part of what Emmanuel S. Nelson later called "American double minority literature" (1983: 70). This role of enhanced marginality enables the narrator to express racial marginalization in relation to his sexuality (Aldama 2005: 49).

In this reading, the narrator is, in other words, bridging marginalized racial and sexual identity categories. Similarly, in her seminal work Borderlands/La Frontera: The New Mestiza (1987), Gloria Anzaldúa develops the concept of mestizaje, framed as a bridging of various identity categories to create a new amalgamation of the self as a multiplicity. Anzaldúa writes:

As a Mestiza I have no country, my homeland cast me out; yet all countries are mine because I am every woman's sister or potential lover. (As a lesbian I have no race, my own people disclaim me; but I am all races because there is the queer of me in all races.) I am cultureless because, as a feminist, I challenge the collective cultural/religious male-derived beliefs of Indo-Hispanics 
and Anglos; yet I am cultured because I am participating in the creation of yet another culture, a new story to explain the world and our participation in it, a new value system with images and symbols that connect us to each other and to the planet. Soy un amasamiento, I am an act of kneading, of uniting and joining that not only has produced both a creature of darkness and a creature of light, but also a creature that questions the definitions of light and dark and gives them new meanings. (1987: 102-103)

As is evident from this quote, the concept of mestizaje, which was originally an ethnic category denoting a person born of parents of different races, was taken up as a conceptual space and identity that combined a multiplicity of categories. Anzaldúa herself was marginalized (in relation to the status quo) in various respects, including nationality and/or homeland, sexuality, gender, culture, value system, and in terms of her relationship to nature or "the planet". She was actively attempting to break down the binary separations that are an organizational method in identity categorization, symbolized here by "light" and "dark", but taking on a multiplicity of meanings through the cataloguing of differences that it presupposes. ${ }^{6}$ What makes Borderlands/ La Frontera such a powerful work is its first person, semi-autobiographical format that allowed Anzaldúa to explore her own multiple "selves". The Chicano/a subject presented in this text (either Anzaldúa writing about herself or, by extension, any mestiza) is, as through a shattered mirror, reflecting multiple identities, far removed from the homogenous understanding of a cohesive and stable Chicano/a identity presented by La Raza Unida Party and in El Plan Espiritual de Aztlán.

There are indications that Chicano Studies is shifting towards an understanding of identity construction as an in-between conceptual space, typified by the concept of nepantla, which means "torn between ways" in Nahuatl, the Aztec language (for an overview of the shift from mestizaje to nepantla see Koegeler-Abdi 2013). Later in her career, Anzaldúa critiqued her previous mestiza theoretical position by moving beyond the reification of identity to a more ambivalent, nepantlera positioning. The nepantla conceptual space is informed by, but not necessarily part of, various identifying categories. If mestizaje is a bridge between categories and a symbol of transitioning, which implies a two- (or more) way relationship between separated and distinguishable concepts, nepantla is the "unstable, unpredictable, precarious, always-in-transition space lacking clear boundaries" between bridges and

${ }^{6}$ Elsewhere in the book Anzaldúa elaborates on the eight different languages she speaks, which are: standard English, working class and slang English, standard Spanish, standard Mexican Spanish, North Mexican Spanish dialect, Chicano Spanish, Tex-Mex and Pachuco (a street-smart slang associated with gangs) (1987: 77). Her take on "borderlands multilingualism" is as unorthodox as it is compelling and could be engagingly applied to other borderland regions of the world. 
a "constant state of displacement" (Anzaldúa 2002: 1). Chicano/a scholars have used the concept of nepantla to help describe conceptual spaces that are otherwise difficult to define due to their ambiguity and changeability. For example, Luis D. León has used the concept of nepantla to describe "religious poetics", which is a "strategy of performed and narrated religious discourse, tactics, and strategies" that allow "culturally derived meanings" to be rearranged in order to change and reinvent the definition of symbols (2004: 4, emphasis in original).

The concept of nepantla has been taken up by Chicana theorists in particular to help delineate a conceptual space marked by in-betweenness by concentrating on one central aspect of Anzaldúa's conceptualization of nepantla: spiritual activism. In an interview, Anzaldúa mentions that the concepts of mestizaje and borderlands have sometimes been used in ways that are vague or overlapping, and went on to specify that nepantla should be used more in terms of the spiritual aspect of in-betweenness (Keating 2002: 142; for more on nepantla and spirituality see Pérez 2007: 30-45; Delgadillo 2011: 8-10; Medina 2014: 167-186). While discussing spirituality in a scientific context can be problematic, ${ }^{7}$ it can be useful as a means by which to deconstruct the "spiritual/material, inner/outer, individual/collective dimensions of life [that are] parts of a larger whole, joined in a complex, interwoven pattern" (Keating 2008: 54). Spirituality can be broadly termed as a subject's "inner work" (Anzaldúa 2002) that is then turned outward to interact with a concrete society and real problems, which are confronted through activism with the aim of bringing about change. As Lara Medina has succinctly put it, "spirituality is fundamentally about relationships" (2014: 167). As a result, Anzaldúa and others (Keating 2005: 6-7; Pérez 2007: 30-32; Medina 2014: 170-171) have emphasized the relationship between the contemplative inner self in relation to the community in conceptualizations of nepantla. In terms of cultural production, Anzaldúa terms this relationship "invoked art" (1987: 67), which means cultural production is infused with "spiritual presence and power" (Pérez 2007: 31) rather than remaining at the level of a commodity. This indicates that there is a relationship between the creator and recipient of "invoked art", or indeed between the artwork itself and the creator and recipient. Rechy frames City of Night as participating in "invoked art" by actively placing the margins of society at the center of the novel in a way that validates humans (Anzaldúa 1987: 67). The narrated struggle for sexual identity is relational with the community, not only in terms of the narrator's relationships with other characters and his deep desire for com-

\footnotetext{
${ }^{7}$ AnaLouise Keating discusses how scholars often avoid the central role of spirituality in Anzaldúa's oeuvre (2008) due to academic training in logical reasoning, empirical demonstrations and rational thought.
} 
munion, but also in terms of the novel's readers (Hernandez-Jason 2014). Rechy's reenvisioning of the marginalized is related to Anzaldúa's use of the "borderlands" metaphor, which means the novel should not be seen as inhabiting the margins of the center's production of meaning, but rather be seen as "a sign of the centrality of the marginalized, the mutable, and the unarticulated in the construction of fuller knowledges and identities" (Pérez 2007: 32). This placing of the borderlands or margins at the center can be framed in terms of nepantla's non-hierarchical structure in which categories are not so much bridged as the space in-between is embraced as a project of becoming, or the destabilization and constant revision of sexual, ethnic and other categories in a complex theoretical process that has no endpoint.

In other words, the concept of nepantla is an ongoing process, and recent scholarly work indicates that it may better describe multiplicity and in-betweenness in Chicano/a and other cultures than the concepts before it, such as mestizaje. It is also, as conceptualized by Anzaldúa, a process with various stages, one of which is Coatlicue, which comes after a subject becomes aware of nepantlera in-betweenness yet before this awareness can be transformed into action (Anzaldúa 1987: 70). Coatlicue represents a resistance to change and new knowledge that is manifested in an intense inner struggle and can "entail the juxtaposition and the transmutation of contrary forces as well as paralysis and depression" (Keating and González-López 2011: 242). The stage after Coatlicue is one of transformation both inwardly and outwardly. For example, the mestiza writer, by embracing her ambiguity, can "modify and shape primordial energy and [is] therefore able to change herself and others into turkey, coyote, tree, or human" (Borderlands 74), which is a symbolic creation of identity and relationship. The narrator never fully reaches this latter stage of transformation in City of Night, and remains in the Coatlicue stage, which is marked by resistance rather than the conscious embracement of ambiguity and in-betweenness to bring about change.

There is a communal element in City of Night in which the narrator is in search of fellowship with others, but he is unable to harness that desire to bring about transformation. In line with Antonio Viego's insight that Chicana Lesbian feminist theory is not necessarily applicable to the particularities of a Chicano, male homosexual text (1999), City of Night may not fit snuggly into theories of nepantla as formulated by Chicana theorists (Anzaldúa 1987, 2002; Pérez 2007; Delgadillo 2011; Medina 2014). When referring to "nepantla" in relation to the novel I mean a point on the continuum to nepantla, perhaps missing the (possibly) necessary transformation of in-betweenness into a constructive and creative interaction with the community. The Coatlicue stage of the nepantla process, which is perhaps more fitting for City of Night, as elaborated below, is made possible by the double matrices of the picaresque novel and Bildungsroman, which present the narrative as a 
doubly coded artifact in which the narrator is a picaro while simultaneously the subject of a Bildungsroman. This double reading opens up a much wider spectrum of meaning for the novel by redirecting the text away from the culturally derived meanings to the text as a nepantlera artifact, or a textual space of in-betweenness complicated by the themes of homosexuality and identity politics.

Many of the major developments in the field of Chicano Studies in this overview, non-exhaustive as it necessarily is, were anticipated in the novel City of Night. That the novel predated the beginning of the Chicano Movement and scholarly concentration on Chicano/a topics suggests that it may have had a role in bringing marginality and multiplicity into a more mainstream and scholarly discussion. To what degree City of Night influenced the future of Chicano Studies and the discussion of ethnic and sexual minorities in the United States is, of course, impossible to quantify. However, the notion that a Chicano author's portrayal of a Chicano narrator deeply involved in the homosexual scene can become a best-selling novel might be indicative of a certain growing sensibility in American society in 1963 (Hernandez-Jason 2014: 34-44). In what follows, I will outline examples of multiplicity and ambiguity in City of Night by relying on the concept of nepantla for a reading of the novel that highlights it as an artifact of in-betweenness. This literary reading should indicate how textual analyses might help scholars to discover nepantlera formulations in various fields, allowing for marginalized voices to be heard.

\section{CITY OF NIGHT}

The opening episode in City of Night takes place during a windstorm raging at night in El Paso, Texas. The narrator is a child and his dog, Winnie, is dying in the dark outside. At first the boy stays with the dog, moving it next to a building to a less windy place and leaving food and a bowl of water, which turns to mud in the dusty wind. He then watches from the calm of the indoors, separated by a window. In the morning the windstorm has passed and the dog is dead. The image of disconnection and separateness, either physical or, more often, emotional, is central to the narrator's presentation of himself and woven into the narrative. Even in the clutches of intimate bodily contact with paying customers in his capacity as a hustler, the narrator presents himself as alone and separate. "I watched other lives, only through a window" (Rechy 1984: 18).

The narrator's arrival in New York City as a young man coincides with an approaching hurricane. The hurricane adds to the city's tense and highstrung nervousness, and the narrator realizes for the first time, "My God! Im 
on an island!"8 (ibid.: 20). Times Square, which is introduced to the narrator by a "queer" (ibid.: 22) sailor on shore leave with the promise of "sexmoney" (ibid.: 22), is another "electric island floating on a larger island of lonesome parks and lonesome apartment houses and knifepointed buildings stretching Up" (ibid.: 21). It pulls him in, acting as a "magnet for all the lonesome exiles jammed into this city" (ibid.: 21). The references to islands, both literal (Manhattan) and figurative (Times Square) add to the feeling of isolation, and words such as "lonesome", "knife" and "exiles" imply displacement and unease. Ostensibly, the narrator wanders around Times Square in search of "sexmoney" because he is indigent. However, behind this practical consideration is a "strange new excitement" at the anticipation of discovering "something of what Ive come to find in this city" (ibid.: 22). So begins the first of many episodes in which the narrator hustles, which, rather than being presented as an active engagement, is described as waiting in a designated area playing "dumb" until approached by a man and being made an offer. Most of the novel is told as passive, disengaged observation of characters on the streets and squares and in the bathrooms and cinemas across the USA, which adds to the central theme of the outsider looking in, which will be important in the treatment of Rechy's construction of multiplicity and in-betweenness below.

The novel is constructed of loosely conjoined episodes, most of which introduce and describe a new character or characters that are not alluded to again, or only briefly, after the episode ends. Mr. King, the narrator's first "score" on Times Square, nevertheless tells him that hustling "aint no good" and asks him, "whattaya wanna hang around the streets for?" (ibid.: 25), which serves as a warning that echoes throughout the novel. In Los Angeles the narrator encounters Destiny, part of the transsexual scene on Pershing Square, who dreams of having an elegant wedding and a faithful "husband". Another Pershing Square regular is Chuck, whom the narrator "knew [...] instinctively" was not at least partially homosexual - he is simply too lazy to do anything more demanding than hustle, which is mostly a passive occupation (ibid.: 129). Another fleeting character is Skipper, once a "Very Beautiful Boy" (ibid.: 149) who carries around newspaper clippings of his past. 0 'Hara, a once renowned character, falls from being a highly desired object to a subject who pines for a much younger object (i.e. "youngman" or hustler), which takes the form of a Greek tragedy, complete with a gossipy choir. There is also a sadomasochist in San Francisco and a woman in New Orleans who owns a bar that welcomes homosexuals, transvestites and hustlers in the hope that her son, whom she had kicked out of the family home for being homosexual, might reappear there. These and other characters make up the

${ }^{8} \mathrm{Sic}$; punctuation and spelling are erratic in the novel as seen here and in the quotes that follow. 
episodic, fragmented and multiple mode of City of Night's narrative, which is important in understanding how the text presents a multiplicity of identities.

The episodic form of City of Night helps to make it a picaresque novel, marked by its temporal principle in which the picaro, in this case the narrator, remains essentially unchanged through his adventures. However, the novel starts in a way that leads the reader to expect an American Dream Bildungsroman, which in turn implies an arch of development, hence structurally creating a doubly coded tension in the text, making these choices of genre important for the structural analysis of representing multiplicity and in-betweenness. The first person narrative introduces the theme of "America" and the "on the road" trope popularized by Jack Kerouac's novel On the Road (2003) published six years prior. "Later I would think of America as one vast City of Night stretching gaudily from Times Square to Hollywood Boulevard [...]" (Rechy 1984: 1). The adverb "later" indicates the temporal arch of the novel, indicating that in the forthcoming pages, possibly near the end of the novel, that "later" point will be reached and a resolution will occur. By opening the novel in such a manner, Rechy is creating what turns out to be a deceptive expectation that, by the "later" stage, the narrator, and hence the reader, will have developed an understanding of both America and the narrator's place in it. Following in this tradition, the novel's first episode takes place during the narrator's childhood in El Paso, Texas on the U.S.-Mexico border. The novel is then presented as a pilgrimage throughout America and as a religiously coded struggle to reach enlightenment or, in more practical terms, to join in communion with society, an important aspect of nepantla, as described above. This journey leads the narrator through the homosexual hustling scenes in some of the major cities of the USA, including New York, Chicago, Los Angles, San Francisco and New Orleans, ending back in El Paso, Texas, and hence full circle back to the place of departure. Besides the same geographical location at the end of the novel as at the beginning, the narrator emphasizes the inevitability of leaving El Paso again in the future (ibid.: 378). It is "A circle which winds around, without beginning, without end" (ibid.: 379). The only development is a negatively coded disillusionment, which is portrayed as the outcome of the Sisyphean task of finding meaning - personal and communal - which indicates that the Bildungsroman tradition has been followed in terms of structure but without what is perhaps its most central aspect, development into a new phase of life for the protagonist. The lack of development is constructed through the disposable episodic manner of the interactions with customers in the hustling scene, which gives the novel the appearance of a continually moving cycle and creates the tension of genre expectations being continually subverted.

The cycle motif is illustrated in an episode in which a bedridden professor hires the narrator to become one of his "angels", which entails that he visit 
the Professor daily and listen to his monologues consisting of anecdotes, aphorisms and digressions. This process is called an "interview" and ends with a sexual act, after which the narrator is paid and he leaves. The following day the process is repeated. The Professor keeps a book - dearer to him than the many tomes of his academic work that are scattered around the messy apartment - in which he keeps photographs of his previous "angels", collected during his eventful life traveling in various parts of the world. The narrator's photograph is added to this book and becomes one of many and, symbolically, one segment in the larger cycle of the Professor's life. That each day is almost identical to the one that came before it - which creates a daily, repeating cycle - mirrors the Professor's loquaciousness, which is hypnotic and circular. The past, in the form of the Professor's reminisces and allusions to previous "angels", consumes the present. Suddenly the interviews end and, a short time later, the Professor dies.

The Professor is a possible reflection of the narrator - or any circular, episodic life, moving from place to place and lover to lover - at old age. After an eventful life, the Professor has not reached a static resolution or definable, settled category. Rather his self comprises the many encounters with individuals from his past and, ironically, he is another such character not only in his own stories but also in the narrative of the novel, adding an element of metafiction. As a subject, he disappears behind his stories, just as the narrator is the sum of his observations, with limited insights into his self. Both characters lack a coherent, conclusive (i.e. categorizable) character but rather inhabit a "space" between categories in the manner of nepantla. For the reader anticipating a narrative in the tradition of the Bildungsroman it can be frustrating to never receive the awaited statement "I am he". Both for the Professor and for the narrator the statement never arrives, leaving the reader in limbo, a reflection of the narrator's Coatlicue state. As mentioned above, in line with Chicana theorists, the concept of nepantla is framed as an embracement of in-betweenness that, painful as the state might possibly be, nevertheless leads to an empowering, middle space between essentialist categories. In this sense, the margin is made into the center, which helps bring about social change through an outward projection of "inner work" (Anzaldúa 2002; Keating 2005: 6-7; Pérez 2007: 30-32; Medina 2014: 170-171). In terms of the novel at hand, an application of the concept of nepantla would presuppose (or at least hope) that the narrator's in-betweenness would lead to an empowering state of multiplicity and in-betweenness more in line with the Bildungsroman and the state of "invoked art" articulate above. City of Night, in its capacity as an artifact of in-betweenness, however, presents the possibility and desire for such empowerment and resolution without actually achieving it; the narrative rather remains is the Coatlicue stage marked by an intense inner struggle. Whether or not the novel's portrayal of in- 
betweenness can, as a result, be considered nepantla is debatable. The text does nevertheless present a narrator with a deconstructed (or in process of being deconstructed) self that inhabits an in-between nepantla-like space without, however, reaching the next, perhaps necessary, step of converting that in-betweenness into a new whole made up of a multiplicity. One might say that the text presents a nepantlera consciousness in the making or the negatively coded, birthing aspect of nepantla as the painful in-between space, which is, in the words of Anzaldúa, "the site of transformation, the place where different perspectives come into conflict and where you question the basic ideas, tenets, and identities inherited from your family, your education, and your different cultures" (2002: 548). The text's constructed state of non-resolution through cycles and lack of definite statements adds to the text as a representation of multiplicity and in-betweenness and is useful in deciphering the move in the Chicano Studies continuum from mestizaje to nepantla.

In addition to the narrator's lack of development is his denial of a static identifying category, also a key aspect of nepantla. This denial takes various forms that coincide with the elements of the picaresque, including: his occupation at the illegal fringes of society and negation of the social norm of monogamy; his inability or lack of desire in holding down a legitimate job; and the already mentioned episodic nature of the narrative told in straightforward realism. ${ }^{9}$ The Chicano scholar Juan Bruce-Novoa has convincingly illustrated that in this manner the narrator is negating the rhetoric of opposites, and by doing so, "raises the problem to a more essential level, that of the conflict between any form, which imposes itself as static order, and freedom", which, he goes on to say, is represented by "fluid chaos" or at least a "disorderly lack of conformity" (1986: 72). The picaresque mode allows for the double minority aspect of the narration to be developed. Being an outsider both in terms of sexuality and racial background allows for the categories to be sidestepped or subverted and an unessentialized version of these themes to be presented in the manner of nepantla. The presentation of a difficult-to-categorize narrator is important as a way of realigning the metaphorical borderlands into the center of social discourse.

The narrator's unessentialized position can be understood as a form of displacement from identity categories. For example, perhaps the defining category of the narrator is his occupation: a hustler. Also important are his regional and ethnic categories: he is from El Paso, Texas; his mother is Mexican and his father is of European descent. The narrator's geographic, ethnic and occupational categories are definable through displacement rather than

${ }^{9}$ This is a general definition of picaresque, a debated term; for more on the evolution of the term, see Mancing (1996: 276-278). 
through static identifying elements, as will be shown. James Clifford pointed out that "practices of displacement" should be seen as "constitutive of cultural meanings rather than as their simple transfer or extension" (1997: 3). A careful reading of the text reveals that seemingly straightforward identities such as ethnicity and sexuality, which would act to consolidate an identitycentered narrative, are subverted and displaced from simple categorization, just as in nepantla the subject inhabits a space betwixt and between bridges in movement rather than bridging categories as an amalgamated cultural hybridity or identifying endpoint.

At the beginning of the novel the narrator comments on his ethnicity, describing his mother as a "beautiful Mexican woman" and, in the next paragraph, mentions her glass case in which there are figurines of the $L a$ Virgen de Guadalupe ${ }^{10}$ (Rechy 1984: 14). The narrator's Mexican background is alluded to several other times, such as with the "Mexican kid song: 'Let is rain, let it rain, Virgin of the Cave..."' (ibid.: 25), but ethnicity is not a central theme in the novel. The narrator's father's ethnicity, for example, is also mentioned (a "man who alternatively claimed French, English, Scottish descent - depending on his imaginative moods" [ibid.: 14]) but not emphasized. Much more important is the father's violence, which "erupted unpredictably over anything" when he would "smash bottles, menacing us with the sharpfanged edges" (ibid.: 15) and also his moments of tenderness, "even more brutal because they didnt last" (ibid.: 15). The narrative in City of Night is established on the premise that categories such as "ethnic" and "American" can "no longer be viewed as easily distinguishable entities" (Christian 1997: 17), a manner of thinking that was not to become popular until the 1990s through the scholarly work of Homi Bhabha, Judith Butler, Stuart Hall and others (Christian 1997: 14-18). At the time of the novel's publication, Chicano/as were not necessarily considered "Americans", ${ }^{11}$ and the manner in which Rechy, without commenting on the narrator's Chicano ethnicity directly, allows him to be the chronicler of marginalized America, which is a form of defining American-ness, is itself a liberatory statement. The narrator's Chicano/a ethnicity, on the one hand, and, on the other, his confident positioning of himself as an American move the narrative beyond

${ }^{10}$ The dark-skinned Virgen de Guadalupe appeared to an Aztec Indian named Juan Diego in 1531, speaking Nahuatl, his native language. Since this time La Virgen de Guadalupe has developed into the Mother of Mexico and has become the primary symbol of religious identity for Mexicans and Mexican Americans alike (León 2004: 61-64).

${ }^{11}$ For a literary example of Chicano/as not considering themselves as "Americans", see Oscar Zeta Acosta's The Autobiography of a Brown Buffalo (1972), where the narrator (a US citizen) states, of his teacher, Miss Anderson: "I looked upon her as one of the few Americans I could trust" (ibid.: 94). For an ethnographic example, see Rivas-Rodriguez (2005: xvi-xvii)9. 
the racial categorizations common at the time by placing the "margins" at the center of the novel, in line with the subjective, first-person format. ${ }^{12}$

This lack of ethnic emphasis is incongruous with much of the Chicano/a literary oeuvre, especially for the 1960s and 70s, and is in large part responsible for Rechy's exclusion from the Chicano/a literary canon for many years. Another reason Rechy's work was not widely considered to be "Chicano/a" was its central subject matter, which overshadowed his literary claims. While other Chicano/a novelists also portrayed homosexuality in the Chicano/a community, Rechy's subject matter was considered more extreme due to the outlaw, hustling underground nature of his characters. ${ }^{13}$ As Frederick Luis Aldama has shown, Rechy's invention of biracial (Mexican/Scottish) bisexual protagonists and his "long-standing emplotment of such ethnosexualized characters" (2005: 47) ${ }^{14}$ have been overlooked in part because Rechy himself has declined to be identified as a Chicano writer. ${ }^{15} \mathrm{He}$ rather identifies himself as a "literary saboteur" or "outlaw writer" (Castillo 1995: 122). However, Rechy's subject matter in City of Night, that of the complex realities and experiences of a Chicano/a character in the borderlands of ethnicity, sexuality, society, lawfulness, body as private/public, and so on, makes his work an important part of the Chicano/a canon today. As Aldama further comments, "it is perhaps because of his sense of himself as a literary saboteur that he so powerfully imagines an otherwise essentialized and/or neglected queer Chicano/a identity and experience" (2005: 48). As I have shown, the text's portrayal of a nepantlera space (or nepantla-like) lends it to new readings of in-betweenness that are gaining importance in the field of Chicano Studies. By sidestepping simple categorization, both in terms of ethnicity and sexuality, Rechy presents a complex picture of a Chicano character in fiction and an example of nepantla or nepantla-in-process that is useful in further theorization of not only Chicano/a issues but also borderlands, both figurative and literal, anywhere.

A careful reading shows yet another layer of in-betweenness in the text, which adds to the multiplicity of possible identifying categories in the Chicano/a community and beyond. The narrator, though working as a hustler, presents the points of view of other hustlers, such as Pete, a streetwise

${ }^{12}$ For an example of a hyper-ethnicized (albeit satirically) Chicano/a novel, see Oscar Zeta Acosta's The Autobiography of a Brown Buffalo (1972).

${ }^{13}$ Juan Bruce-Novoa has shown that in the decade in which the Chicano Movement began (1959-1970), five of the seven Chicano/a novels published utilize homosexuality or attitudes towards homosexuality as an important theme (three of them by Rechy) (1986: 70).

${ }^{14}$ Since the publication of City of Night Rechy has introduced readers to many other characters that self-identify in a similar manner (Aldama 2005: 47).

${ }^{15} \mathrm{~A}$ longstanding discussion in Chicano Studies centers around the definition of a Chicano/a writer. If it is defined as a "Chicano who writes", as Rechy believes it should be, "obviously I am that" (García 2003: 45), he concludes. 
and hardened "youngman" who insists that, "Whatever a guy does with other guys, if he does it for money, that dont make him queer. Youre still straight. When you start doing it for free, with other young guys, that you start growing wings" (Rechy 1984: 40). To prove his masculinity, Pete, and on occasion the narrator as well, will "go" with girls. Hustling is understood to be an occupation. Though one would assume some level of homosexual desire on the part of the narrator that would allow for this non-traditional (and illegal) occupation, this assumption is undermined throughout the novel. By analogy, to assume that a factory worker has a particular penchant for machinery is to prescribe emotions and ideas to him or her that are not necessarily founded. Based on what is presented in the text, it is clear that the narrator does not allow himself to desire others, at least consciously and explicitly; rather he is intent on being the object of desire. This may be a fine line, but one that nevertheless constructs the element of multiplicity and in-betweenness that marks the text as a whole.

There is evidence that the narrator's wish to be the object of desire may have more to do with codes of homosexual conduct than with the narrator's sexuality, however. As Pete's quote above illustrates, one is only "queer" if one goes with younger males for free. There is a spectrum of "queer-ness", in other words. One step to being more "queer" is to be a paying customer. The masculine role in the relationship (i.e. not being "queer") is established by not desiring other men. The narrator is, to some extent in any case, constructing a "masculine" persona in order to be more desired. As a more desired object, he will be paid for sexual contact, rather than being in the weaker, desiring position of having to pay for it (as older, more effeminate men will do). Having taken into account the codes of the homosexual subculture and hustling scene, however, and assuming that "homosexuality" means desiring another person of the same sex, one might expect the narrator to confess his desire (or lack thereof) at some point, hence firmly establishing his bona fides as a homo-, bi- or heterosexual man. This does not occur, and the reader is left in some doubt as to which category the narrator belongs to, at least definitively. This leaves open the question as to whether other possibilities exist besides these well-established sexual categories. Perhaps the narrator is in-between categories in a nuanced and personal form of sexuality that does not conform to the reader's preconceived categories of sexual identity. Another possibility, and probably the most likely, is that societal and familiar pressures and guilt cause the narrator to avoid embracing a clear-cut homoor bisexual identity. However, by the end of the novel this central question is never resolved, which is probably a more realistic portrayal of homosexual identity formation in the 1960s than any "resolution" (i.e. categorization) could be. In line with Chicana theorists and the Bildungsroman genre, in order to achieve a nepantla space the narrator might be expected to resolve his 
in-betweenness by embracing the fragmented or marginalized nature of his sexuality. This, however, does not occur explicitly due to the circular, episodic adventures of the picaro narrator with the result that the nepantlera tension of in-betweenness is highlighted at the expense of making a new, cohesive nepantlera state discernible.

Pete, the streetwise and hardened hustler, drops his persona at one point and admits to emotions of longing for closeness and friendship or possibly a romantic interest in the narrator. The fact that the reader is left in doubt of Pete's motivation is an example of the mode of multiplicity and in-betweenness in the novel, and it is constructed through the narrator's observational, outsider point of view and tone, which, due to his capacity as narrator, is the center of the novel, yet remains an unresolved center due to the fact that he does not explain or clarify events but rather presents them without overly commenting. After spending the day together talking, Pete asks if he can spend the night in the narrator's rented room because it is late. In the shared bed, the narrator states, "I felt his hand, lightly, on mine. Neither of us moved. Moments passed like that. And now his hand closes over mine, tightly. And that was all that happened" (ibid.: 51). Is Pete a closeted homosexual longing for physical contact with the narrator or simply a lonely young man in search of intimacy and friendship? Or perhaps the relationship should be defined in terms that move past the homo-/ heterosexual dichotomy? One might assume from the social context of the time that both characters harbor hidden homosexual urges but are too afraid to express them. The text, however, remains ambiguous on the subject and taken as an artifact of in-betweenness and double coding - as opposed to a commentary on external factors - the reader cannot be definitely sure one way or the other. In any case, the text presents the characters as existing beyond the simple dichotomy of homo- and heterosexuality and movingly illustrates that as far as sexuality is concerned, there is also an area of in-betweenness, painful and inconclusive as it may be. The only definite outcome of this attempt at closeness is the end of the pair's friendship.

Towards the end of the novel, the narrator creates a sense of tension by alluding to his emotional state and possible desire for others, as illustrated in an episode in New Orleans in which he becomes attached to Jeremy. Whether or not the narrator desires Jeremy is never definitely affirmed. If desire does exist, it is to be fled from. Male- male sex is alluded to but neither described in detail nor condoned or condemned explicitly. The fact that it takes place is to suggest desire, but the description is negatively coded, as in the following quote: "Ponderously exhausted after the determined ejaculation - which had come, strained up to the actual moment of discharge, in those doubly orgasmic thrusts as if I had tried to drain from myself something infinitely more than the mere sperm" (ibid.: 343). The words "ponderously exhaust- 
ed", "determined", "strained", and "drain" have negative connotations. This description is followed by an admission by the narrator that he had gone with the man, who is Jeremy, despite knowing that he was not a "score" (i.e. that he would pay). This goes against the narrator's masculine, non-desiring persona. However, after making this confession, he adds that he went with him in a state of "pilled and liquored panic" (ibid.: 343), hence undermining Jeremy's desirability. In the morning the narrator's only wish is to "Escape" (ibid.: 344) but he is convinced to stay for a cigarette, during which Jeremy philosophizes about sex, desire and love. Besides Jeremy's well spoken, cerebral manner, which is evidenced through his rhetoric, he is described as "a well-built, masculine man in his early 30 s [...] He is intensely, moodily handsome" (ibid.: 345 ). The narrator wonders why such a man would "pay another male when he could obviously make it easily and mutually in any of the bars" (ibid.: 345). The money Jeremy has offered the narrator remains unaccepted on the table next to the bed. Bluntly, after some conversation, Jeremy says, "You want, very much, to be loved - but you dont want to love back, even if you have to force yourself not to" (ibid.: 346). Jeremy admits to having over-heard the narrator's earlier confession to two "scores" in a bar, in which the narrator said, "Im not at all the way you think I am. Im not like you want me to be, the way I tried to look and act for you: not unconcerned, nor easygoing - not tough: no, not at all" (ibid.: 341). Jeremy believes he has seen through the narrator's façade, which also allows the reader a glimpse into his hidden emotions. The narrator has stated what he isn't ("like you want me to be") but not what he is, however. Prompted by Jeremy, the narrator thinks about "love" and, though he knows this is not what Jeremy has in mind, associates it with his mother and even his father. Barbara, a woman he had a fling with in El Paso, also crosses his mind as "the least dangerous thought" (ibid.: 347) and the memory of Dave, a man he grew close to in Los Angeles but left abruptly, "sprang forward" (ibid.: 347). The fact that Dave's memory "sprang forward" suggests that the "love" associated with Dave is inadvertent or unconscious. Pete, Lance and Mr. King are also mentioned in terms of the narrator's "awareness of [their] pain" (ibid.: 347), which, he admits, "could be, perhaps, a shape of 'love'" (ibid.: 347). But, out loud, he says, "No [...] Ive never loved any one" (ibid.: 347). Jeremy again brings the reader's attention to the possibility that the narrator fits into one of the dominant sexual categories. He asks, "Do you always go for money - only?" The narrator answers affirmatively but admits, to the reader, that it is a lie. Later Jeremy says, "I got the impression that the money [the customers] gave you wasn't the important thing - that you were, maybe, compulsively playing a game" (ibid.: 348). The narrator explains - to himself and the reader - that his sexuality is beyond the hetero-/homosexual binary and also connects his current state to his childhood when his father and his friends would pay 
to allow them to sexually abuse him (ibid.: 14). "How impossibly difficult it seemed to explain to him that it was the mere proffering of the sexmoney that mattered; the unreciprocated sex: the manifestations that I was really Wanted" (ibid.: 348).

The narrator's inability to express his sexual orientation and emotions to Jeremy extends to the reader, who must piece together an image of the narrator that does not conform to readily available categories of sexual characterization. To what extent the reader finds the narrator reliable, both in his description of being "Wanted" (ibid.: 348) above and in other instances, adds to the text's ambiguity. Sex, as with most things in life, is rarely so simple as to be described in one phrase, as the narrator does in the quote above. The reader might suspect that various other factors come into play here that the narrator is either unaware of or is unwilling to present. This evasion of full frankness leads to an unsettled ending for the novel, and the expectation of epiphany, self-discovery and development is never met. As already mentioned, the narrator ends his story back in El Paso, Texas, as an outsider looking at the world, separated not only by physical and emotional distances but by the very expectations of a society that demands simple "yes" or "no" responses to questions, such as ethnicity and sexuality, that might prove to be more complex in their multiplicity and in-betweenness than a definitive response would warrant. In this sense the narrative remains in the Coatlicue state of nepantla and does not reach the spiritual activist stage presupposed by Chicana theorists. However, this allows for the text to present the tension of in-betweenness created by conflicting narrative matrices, that of the cyclical picaresque and the foiled temporal resolution of the Bildungsroman. By presenting a narrator that never reaches static categorization, Rechy anticipated the move in the field of Chicano Studies from consolidated identity-centered theorizations to a deconstructed, destabilized paradigm represented by the concept of nepantla.

\section{CONCLUSION}

The narrator's multiplicity and in-betweenness are constructed through point of view, tone, and theme in the novel. The first-person point of view and the trappings of the Bildungsroman create the anticipation of honesty, confession and access to the narrator's side of the story, or emotional position. This, however, does not, for the most part, occur. The narrator remains a cool observer of others, describing characters, cities, streets, squares and bars episodically, expressed in a realistic style. In City of Night, John Rechy creates a narrator that stands in for the marginalized aspects of the 
Chicano/a community and, through the first person narrative, places the margins at the center of the narrative. Arriving at the point in US history where the injustices suffered by the Mexican American community were being transformed into community organization and activism, which would cumulate in the Chicano Movement, the novel acted as a deconstructive narrative by showing that simple categorization is rarely possible or fruitful, or in any case not possible for this particular narrator. The novel's predation of a broader movement, as well as its popularity and the debates that it ignited, suggest that its representation of marginalized voices may have helped to galvanize individuals into activism against injustice, which is to extend the narrative beyond the text to allow for the "spiritual activism" that is inherent to the concept of nepantla. It was not until the later 1970s and beyond, however, that Rechy's work was slowly accepted as part of the Chicano literary canon, which, among other things, is a testimony to his unessentialized representation of ethnicity in City of Night and other novels. Ethnicity was one part of the narrator's overall experience and not a prime motivator. Just as one would not expect an Anglo-American writer to necessarily bring up his or her whiteness, Rechy let his American experience eclipse his ethnic status, an anomaly for Chicano/a novelists of the time. Sexuality was much more important, but also not described in terms of simplistic categories. Rather the narrator is presented as inhabiting an ambiguous and still unclear identity, made up of conflicting and contradictory emotions, pressures and desires. By the end of the novel, one cannot say that the narrator belongs to any given identifying category in simplistic, static and stable terms. It is, however, possible to describe the narrator's conceptual space as in-between these multiple categories and influenced by them, which is the central tenet of nepantla. In other words, he occupies a space that is in-between the dichotomies that Pérez-Torres stated, in the excerpt at the beginning of this paper, are the object of the Chicano/a scholar's critical gaze. Narratives, through their representation of individuals, groups and relationships, can usefully illustrate complex societal interactions. Together with scholarly work, activism and a broad societal dialogue, narratives can help "redraw the boundaries that set up divisions between knowledge, action, and being" (Pérez-Torres 2010: 411). Through the analysis of texts such as City of Night, scholars can broaden society's understanding of acceptable identifying categories and affect the way society perceives itself.

In this manner, City of Night is a novel that represents and creates the conceptual space of nepantla as mentioned above. Gloria Anzaldúa critiqued her own mestiza theoretical stance, which reifies identity into categories that may miss the complexities of the borderlands experience, both figurative and literal. She indicated that a paradigmatic shift is taking place, and, for its relation to City of Night, the description is worth quoting at length. 
We stand at a major threshold in the extension of consciousness, caught in the remolinos (vortices) of systematic change across all fields of knowledge. The binaries of colored/white, female/male, mind/body are collapsing. Living in nepantla, the overlapping space between different perceptions and belief systems, you are aware of the changeability of racial, gender, sexual, and other categories rendering the conventional labelings obsolete. Though these markings are outworn and inaccurate, those in power continue using them to single out and negate those who are "different" because of color, language, notions of reality, or other diversity. (2002: 541)

If the indications that Chicano Studies is moving beyond concepts such as mestizaje and into a more nepantlera paradigm are correct, as Anzaldúa and others have suggested (2002; Koegeler-Abdi 2013), City of Night may prove to be a key text for better understanding how identity formation can be conceptually framed without relying on traditional identifying categories, or combinations of these categories. As illustrated in this paper, City of Night's narrator and narrative are constructed so as to represent multiplicity and inbetweenness beyond binaries such as homo- or heterosexual and ethnic or American. In this sense, Rechy's work might be taken as a form of nepantla, and illustrates how City of Night continues to anticipate important developments in the field of Chicano Studies and beyond.

\section{REFERENCES AND SOURCES}

Acosta, Oscar Zeta. 1972. The Autobiography of a Brown Buffalo. San Francisco: Straight Arrow Books.

Acosta, Oscar Zeta. [1973] 1989. The Revolt of the Cockroach People. New York: Vintage Books.

Alarcon, Daniel Cooper. 1997. The Aztec Palimpsest. Mexico in the Modern Imagination. Tucson: University of Arizona Press.

Aldama, Frederick Luis. 2005. Brown on Brown. Chicano/a Representations of Gender, Sexuality, and Ethnicity. Austin: University of Texas Press.

Anzaldúa, Gloria. 1987. Borderlands/La Frontera. The New Mestiza. San Francisco: Aunt Lute Books.

Anzaldúa, Gloria and AnaLouise Keating, eds. 2002. This Bridge We Call Home. Radical Visions for Transformation. New York: Routledge.

Barrios, Gregg. 2013. "A First Gay Novel, a Poor Latino Boyhood and the Confluence”. Available at: http://www.nytimes.com/2013/12/01/us/a-first-gay-novel-a-poor-latino-boyhoodand-the-confluence.html?_r=0 (accessed 10 January 2015).

Bruce-Novoa, Juan. 1986. "Homosexuality and the Chicano Novel". Confluencia 2/1: 69-77.

Casillo, Charles. 2013. "Fifty Years of Rechy's 'City of Night'”. Available at: http://lareviewofbooks.org/essay/fifty-years-of-rechys-city-of-night (accessed 10 January 2015).

Castillo, Debra. 1995. "Outlaw Aesthetics. Interview with John Rechy." Diacritics 25/1: 113125. [http://dx.doi.org/10.2307/465368] 
Christian, Karen. 1997. Show and Tell. Identity as Performance in U.S. Latino/a Fiction. Albuquerque: University of New Mexico Press.

Clifford, James. 1997. Routes. Travel and Translation in the Late Twentieth Century. Cambridge, London: Harvard University Press.

Delgadillo, Theresa. 2011. Spiritual Mestizaje. Religion, Gender, Race, and Nation in Contemporary Chicana Narrative. Durham, London: Duke University Press. [http://dx.doi. org/10.1215/9780822394365]

"El Plan Espiritual de Aztlán”. 1969. Available at: http://www.cwu.edu/ mecha/documents/ plan_de_aztlan.pdf (accessed 10 January 2015).

García, Ramón. 2003. "Interview with John Rechy". Chasqui 32/1: 39-46. [http://dx.doi. org/10.2307/29741766]

Gómez-Quiñones, Juan. 2010. "Toward a Perspective on Chicano History." In The Chicano Studies Reader. An Anthology of Aztlán 1970-2010. Chon A. Noriega et al., eds. Los Angles: UCLA Chicano Studies Research Center Press, 28-75.

Gonzales, Rodolfo “Corky”. 1967. “I am Joaquin”. Available at: http://www.latinamericanstudies.org/latinos/joaquin.htm (accessed 10 January 2015).

Hames-García, Michael. 2000. “Dr. Gonzo's Carnival. The Testimonial Satires of Oscar Zeta Acosta". American Literature 72/3: 463-493. [http://dx.doi.org/10.1215/00029831-723-463]

Hernández, Ellie D. 2009. Postnationalism in Chicano/a Literature and Culture. Austin: University of Texas Press.

Hernandez-Jason, Beth. 2014. "The Act of Reading John Rechy. Transnational Intertexts and Readers". Available at: http://escholarship.org/uc/item/9412s8fb (accessed 25 March 2015).

Keating, AnaLouise. 2002. "Writing, Politics, and las Lesberadas. Platicando con Gloria Anzaldúa." In Chicana Leadership. The Frontiers Reader. Yolanda Niemann Floresm et al., eds. Lincoln: University of Nebraska Press, 120-143.

Keating, AnaLouise, ed. 2005. Entre Mundos/Among Worlds. New Perspectives on Gloria Anzaldúa. New York: Palgrave Macmillan.

Keating, AnaLouise. 2008. "'I'm a Citizen of the Universe'. Gloria Anzaldúa's Spiritual Activism as Catalyst for Social Change." Feminist Studies 34/1/2: 53-69.

Keating, AnaLouise and Gloria González-López, eds. 2011. Bridging. How Gloria Anzaldúa's Life and Work Transformed our Own. Austin: University of Texas Press.

Kerouac, Jack. [1957] 2003. On the Road. New York: Penguin Classics.

Koegeler-Abdi, Martina. 2013. "Shifting Subjectivities. Mestizas, Nepantleras, and Gloria Anzaldúa's Legacy". MELUS 38/2: 71-88. [http://dx.doi.org/10.1093/melus/mlt016]

León, Luis D. 2004. La Llorona's Children. Religion, Life, and Death in the U.S.-Mexican Borderlands. Berkeley, Los Angeles, London: University of California Press.

Mancing, Howard. 1996. “The Protean Picaresque”. In The Picaresque. Tradition and Displacement. Giancarlo Maiorino, ed. Minneapolis: University of Minnesota Press, 273-291.

Medina, Lara. 2014. "Nepantla Spirituality. My Path to the Source(s) of Healing”. In Fleshing the Spirit. Spirituality and Activism in Chicana, Latina, and Indigenous Women's Lives. Elisa Facio and Irene Lara, eds. Tucson: The University of Arizona Press, 167-186.

Navarro, Armando. 2000. La Raza Unida Party. A Chicano Challenge to the U.S. Two-Party Dictatorship. Philadelphia: Temple University Press. 
Nelson, Emmanuel S. 1983. "John Rechy, James Baldwin and the American Double Minority Literature". Journal of American Culture 6/2: 70-74. [http://dx.doi.org/10.1111/j.1542734X.1983.0602_70.x]

Noriega, Chon. 2010. "The Dissension of Other Things". In The Chicano Studies Reader. An Anthology of Aztlán 1970-2010. Chon A. Noriega et al., eds. Los Angles: UCLA Chicano Studies Research Center Press, 1-6.

Ortiz Taylor, Sheila. 1982. Faultline. San Francisco: Naiad Press.

Paredes, Américo. 1958. With His Pistol in His Hand. A Border Ballad and Its Hero. Austin: University of Texas Press.

Peñalosa, Fernando. 2010. "Toward an Operational Definition of the Mexican American". In The Chicano Studies Reader. An Anthology of Aztlán 1970-2010. Chon A. Noriega et al., eds. Los Angles: UCLA Chicano Studies Research Center Press, 16-27.

Pérez, Laura E. 2007. Chicana Art. The Politics of Spiritual and Aesthetic Altarities. Durham: Duke University Press. [http://dx.doi.org/10.1215/9780822389880]

Pérez-Torres, Rafael. 2010. "Remapping the World. Introduction". In The Chicano Studies Reader. An Anthology of Aztlán 1970-2010. Chon A. Noriega et al., eds. Los Angles: UCLA Chicano Studies Research Center Press, 405-411.

Rechy, John. [1963] 1984. City of Night. New York: Grove Press.

Rodriguez-Rivas, Maggie, ed. 2005. Mexican Americans and World War II. Austin: University of Texas Press.

Vargas, Zaragosa. 2005. Labor Rights Are Civil Rights. Mexican American Workers in TwentiethCentury America. Princeton: Princeton University Press.

Viego, Antonio. 1999. "The Place of Gay Male Chicano Literature in Queer Chicana/o Cultural Work". Discourse 21/3: 111-131.

\section{VIŠESTRUKOST CHICANO/A IDENTITETA I MEĐUSNOST U ROMANU CITY OF NIGHT JOHNA RECHYJA}

U ovome se radu, na temelju književne analize romana City of Night Johna Rechyja, nudi opis aspekata u kojima je taj roman bio prethodnik mnogih ključnih trendova u interdisciplinarnom području Chicano studija. Riječ je, primjerice, o prikazu marginaliziranih aspekata iskustva Chicano/a na neesencijalistički način te shvaćanje Chicano/a identiteta izvan okvira tradicionalnih kategorija, posebice što se tiče etničnosti i seksualnosti. Rechyjev pripovjedač nikada ne dolazi do rješenja, premda je roman naizgled uokviren kao bildungsroman. Štoviše, likovi iz američkog polusvijeta koje pripovjedač upoznaje kao muška prostitutka uvode se epizodno, što roman čini sličnim pikarskom romanu. Rechy stalno potkopava pretpostavke o homoseksualnoj želji, čime destabilizira kategorizaciju pripovjedača kao homoseksualca, biseksualca ili heteroseksualca, stvarajući tako konceptualni prostor međusnosti u kojem pripovjedač zasigurno ne pripada nijednoj jasno određenoj seksualnoj kategoriji. Rechyjev pripovjedač, nasuprot trendovima Chicano/a fikcije u to doba, svoje meksičko-američko porijeklo komentira neizravno, umanjujući važnost etničnosti (koja je igrala presudnu ulogu u kasnijem pokretu Chicano), što čini kako bi svojem pripo- 
vijedanju dao značajke višestrukosti i međusnosti. Navedeni se procesi u radu smještaju u konceptualni okvir nepantle teoretičarke Chicano studija, Glorie Anzaldúa. Rad će stoga biti zanimljiv znanstvenicima koji se bave tekstualnim izvorima da bi analizirali prikaze višestrukosti i međusnosti, odnosno shvaćanjem tekstova kao narativa koji proširuju kategorije identiteta prihvaćene u našim društvima. Roman City of Night pokazuje da narativi mogu predvidjeti važna kretanja u shvaćanju višestrukih identiteta i međusnosti među znanstvenicima i u društvu uopće.

Ključne riječi: nepantla, višestrukost, međusnost, John Rechy, Chicano studiji 